Supporting Information

\title{
Organic and Organometallic Derivatives of Dihydrogen-encapsuled [60]Fullerene
}

Yutaka Matsuo, Hiroyuki Isobe, Takatsugu Tanaka, Yasujiro Murata, Michihisa Murata, Koichi Komatsu and Eiichi Nakamura

Nakamura Functional Carbon Cluster Project, ERATO, Japan Science and Technology Agency and Department of Chemistry, The University of Tokyo, Hongo, Bunkyo-ku, Tokyo

113-0033, Japan, and Institute for Chemical Research, Kyoto University, Uji, Kyoto

$$
\text { 611-0011, Japan }
$$

\section{Table of Contents}

1. Procedures for Synthesis of 1-4 S2

2. X-ray Crystallographic Date for 2 and $3 \quad$ S5

3. Theoretical Calculation of $\mathrm{C}_{60} \mathrm{H}_{5}$ Anion $\quad \mathrm{S} 8$

4. NMR and MS Spectra of 1-4 S9 


\section{Procedures for Synthesis of 1-4}

General. All experiments in this paper were performed with the use of an abundant $\mathrm{H}_{2}$-containing $\mathrm{H}_{2} @ \mathrm{C}_{60}\left(\mathrm{H}_{2} @ \mathrm{C}_{60} / \mathrm{C}_{60}=4 / 1\right) .{ }^{1} \mathrm{H}(400 \mathrm{MHz}, 500 \mathrm{MHz})$ and ${ }^{13} \mathrm{C}$ $(100 \mathrm{MHz}, 125 \mathrm{MHz})$ NMR spectra were recorded on a JEOL ECA500 spectrometer. ${ }^{1} \mathrm{H}$ and ${ }^{13} \mathrm{C}$ NMR spectra were referenced to internal tetramethylsilane $(\delta 0.00)$ and residual solvent carbons $\left(\mathrm{CDCl}_{3}: \delta 77.0\right.$; THF: $\left.\delta 67.4\right)$, respectively. Except the signal due to encapsulated hydrogen, NMR signals matched with those of empty authentic samples. Mass spectra were measured on a JEOL JMS-T100LC APCI/ESI-TOF mass spectrometer.

Synthesis

of 6,9,12,15,18-Pentaphenyl-1,6,9,12,15,18-hexahydro $\left(C_{60}-I_{h}\right)[5,6]$ fullerene-incar-dihydr ogen (1). To a white powder of $\mathrm{CuBr} \cdot \mathrm{SMe}_{2}(22 \mathrm{mg}, 0.10 \mathrm{mmol})$ was added a THF (0.5 $\mathrm{mL})$ solution of $\mathrm{PhMgBr}(0.10 \mathrm{mmol})$ and then was added $\mathrm{H}_{2} @ \mathrm{C}_{60}(5.0 \mathrm{mg}, 0.0069$ $\mathrm{mmol})$ in 1,2-dichlorobenzene $(0.5 \mathrm{~mL})$ at room temperature. After stirring for 12 hour at $30{ }^{\circ} \mathrm{C}$, proceeding of the reaction was checked with HPLC (Buckyprep column; eluent: tol $/ 2$-propanol $=7 / 3$; flow rate: $1.0 \mathrm{~mL} / \mathrm{min}$; retention time: ca. 5.7 $\mathrm{min})$ and quenched with saturated aqueous solution of $\mathrm{NH}_{4} \mathrm{Cl}(0.5 \mathrm{~mL})$. The mixture was diluted with toluene and filtered by passing through a pad of silica gel. The filtrate was evaporated under reduced pressure to a small volume, and diluted quickly with $\mathrm{MeOH}$ to precipitate orange powder. Solid was collected by filtration and washed with $\mathrm{MeOH}$ and hexane to obtain the title compound (92\% yield). ${ }^{1} \mathrm{H}$ NMR $\left(500 \mathrm{MHz}, \mathrm{CDCl}_{3} / \mathrm{CS}_{2}\right.$ 1/1): $\delta-10.39$ (s, $2 \mathrm{H}(80 \%)$, incar $\left.-\mathrm{H}_{2}\right), 5.29(\mathrm{~s}, 1 \mathrm{H}$, FullereneCp-H), 7.0-7.7 (m, 25H, Ph). ${ }^{13} \mathrm{C}$ NMR (125 MHz, $\left.\mathrm{CDCl}_{3} / \mathrm{CS}_{2} 1 / 1\right): \delta 58.58$ $\left(\mathrm{C}_{60}-\mathrm{Ph}-\mathrm{sp}^{3}\right), 58.73\left(\mathrm{C}_{60}-\mathrm{Ph}-\mathrm{sp}^{3}\right), 60.81\left(\mathrm{C}_{60}-\mathrm{Ph}-\mathrm{sp}^{3}\right), 62.97$ (FullereneCp-sp $\left.{ }^{3}\right), 127.05$, $127.35,127.52,127.62,127.83,127.97,128.47,128.67$, and $128.76(o-, m-$, and $p-P h)$, $139.33,139.37,143.05,143.64,143.97,144.00,144.21,144.32,145.27,145.55,145.61$, $146.09,147.07,147.10,147.42,147.73,148.07,148.16,148.38,148.65,148.71,151.48$,

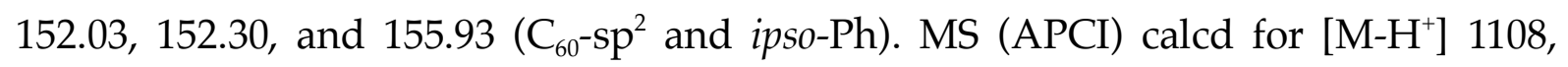
found 1108 .

Synthesis

of $\left[6,9,12,15,18-P e n t a p h e n y l-1,6,9,12,15,18\right.$-hexahydro $\left(C_{60}-I_{h}\right)[5,6]$ fulleren-incar-dihydr ogen-1(6H)-yllpotassium (2). A Schlenk tube was charged with $\mathrm{C}_{60} \mathrm{Ph}_{5} \mathrm{H}(4.0 \mathrm{mg}$, $0.0036 \mathrm{mmol})$ and excess amount of potassium hydride $(4.0 \mathrm{mg}, 0.10 \mathrm{~mol})$ which was washed with dried hexane. Addition of THF $(1.0 \mathrm{~mL})$ to the Schlenk tube gave dark 
red solution with evolving $\mathrm{H}_{2}$ gas. After stirring for $10 \mathrm{~min}$ at $25^{\circ} \mathrm{C}$, the reaction mixture was transferred to a centrifugation tube via cannula. The dark red solution was separated from potassium hydride by centrifugation and transferred to a Schlenk tube. Solvent was removed under reduced pressure to obtain dark red microcrystalline solid which was washed with dried hexane to obtain the title compound (95\% yield). ${ }^{1} \mathrm{H}$ NMR (500 MHz, THF- $d_{8}$ ): $\delta-9.79$ (br s, $2 \mathrm{H}(80 \%)$, incar $\left.-\mathrm{H}_{2}\right)$, 7.03 (br s, 15H, $m$ - and $p$-Ph), 7.91 (br s, 10H, o-Ph). $\left.{ }^{13} \mathrm{C} \mathrm{NMR} \mathrm{(125} \mathrm{MHz,} \mathrm{THF-} d_{8}\right): \delta$ $62.40\left(\mathrm{C}_{60}-\mathrm{sp}^{3}\right), 126.10(p-\mathrm{Ph}), 128.08(m-\mathrm{Ph}), 128.99$ (FullereneCp), $129.41(o-\mathrm{Ph})$, $143.26\left(\mathrm{C}_{60}-\mathrm{sp}^{2}\right), 146.38\left(\mathrm{C}_{60}-\mathrm{sp}^{2}\right), 146.68\left(\mathrm{C}_{60}-\mathrm{sp}^{2}\right), 147.33$ (ipso-Ph), $147.45\left(\mathrm{C}_{60}-\mathrm{sp}^{2}\right)$, $149.46\left(\mathrm{C}_{60}-\mathrm{sp}^{2}\right), 160.08\left(\mathrm{C}_{60}-\mathrm{sp}^{2}\right)$.

Synthesis

of $\left(\eta^{5}\right.$-cyclopentadienyl) $\left[6,9,12,15,18\right.$-Pentaphenyl-1,6,9,12,15,18-hexahydro $\left(C_{60}-I_{h}\right)[5,6]$ fulleren-incar-dihydrogen-1(6H)-yl]iron(II) (3). Compound $\mathbf{1}(5.0 \mathrm{mg}, 0.0045 \mathrm{mmol}$ ) and $\left[\mathrm{FeCp}(\mathrm{CO})_{2}\right]_{2}(2.4 \mathrm{mg}, 0.0068 \mathrm{mmol})$ in $\mathrm{PhCN}(1.00 \mathrm{~mL})$ was degassed under reduced pressure $(\sim 0.3 \mathrm{mmHg})$ over $30 \mathrm{~min}$ at $0{ }^{\circ} \mathrm{C}$, and the resulting mixture was stirred at $180{ }^{\circ} \mathrm{C}$ for $20 \mathrm{~h}$. Solvent was removed under reduced pressure at $50^{\circ} \mathrm{C}$, and the resulting black solid was extracted with toluene $(10 \mathrm{~mL})$. The red toluene solution was filtered with a pad of silica gel, and toluene was evaporated to obtain orange microcrystals of the title compound (71\% yield). ${ }^{1} \mathrm{H}$ NMR $(500 \mathrm{MHz}$, $\left.\mathrm{CDCl}_{3} / \mathrm{CS}_{2} 1 / 1\right): \delta-10.44\left(\mathrm{~s}, 2 \mathrm{H}(80 \%)\right.$, incar $\left.-\mathrm{H}_{2}\right), 3.20(\mathrm{~s}, 15 \mathrm{H}, \mathrm{Cp}), 7.35(\mathrm{t}, 10 \mathrm{H}, m-\mathrm{Ph})$, $7.40(\mathrm{t}, 5 \mathrm{H}, p-\mathrm{Ph}), 7.94(\mathrm{~d}, 10 \mathrm{H}, o-\mathrm{Ph}) .{ }^{13} \mathrm{C}$ NMR $\left(125 \mathrm{MHz}, \mathrm{CDCl}_{3} / \mathrm{CS}_{2}\right.$ 1/1): $\delta 58.53$ $\left(\mathrm{C}_{60}-\mathrm{sp}^{3}\right), 73.37\left(\mathrm{C}_{5} \mathrm{H}_{5}\right), 92.98$ (FullereneCp), $127.73(p-\mathrm{Ph}), 127.84(m-\mathrm{Ph}), 129.29(o-\mathrm{Ph})$, $143.20\left(\mathrm{C}_{60}-\mathrm{sp}^{2}\right), 143.36$ (ipso-Ph), $144.17\left(\mathrm{C}_{60}-\mathrm{sp}^{2}\right), 147.54\left(\mathrm{C}_{60}-\mathrm{sp}^{2}\right), 148.34\left(\mathrm{C}_{60}-\mathrm{sp}^{2}\right)$, $148.59\left(\mathrm{C}_{60}-\mathrm{sp}^{2}\right), 152.73\left(\mathrm{C}_{60}-\mathrm{sp}^{2}\right)$. MS (APCI) calcd for [M- 1229 , found 1229.

\section{6,12,15,18-Tetra(piperidin-1-yl)-6,12,15,18-(tetrahydro)oxireno[2', 3':1,9]( $\mathrm{C}_{60}-\mathrm{I}$} $\left.{ }_{\mathrm{h}}\right)[5,6]$ fullerene-incar-dihydrogen (4a). A mixture of $\mathrm{H}_{2} @ \mathrm{C}_{60}(1.00 \mathrm{mg}, 1.4 \mu \mathrm{mol})$ and piperidine $(0.71 \mathrm{mg}, 8.3 \mu \mathrm{mol})$ in $\mathrm{O}_{2}$-saturated solution of $20 \%$ DMSO in chlorobenzene $(0.1 \mathrm{~mL} / 0.4 \mathrm{~mL})$ was stirred at ambient temperature for $12 \mathrm{~h}$. The yield of the title compound $4 \mathbf{a}$ was estimated to be $80 \%$ by HPLC analysis (ODS column) using 9,10-dibromoanthracene as an internal standard. The title compound 4a was isolated and purified by the same procedure reported for $\mathrm{C}_{60} .{ }^{1} \mathrm{H}$ NMR (500 $\mathrm{MHz}, \mathrm{CDCl}_{3}$ ) $\delta-10.77$ (s, 2H (80\%), incar- $\mathrm{H}_{2}$ ), 1.53-1.79 (br m, 24H), 3.10-3.37 (br m, $16 \mathrm{H})$; MS (ESI) calcd for $\left[\mathrm{M}^{+}\right]$1074, found 1074.

6,12,15,18-Tetra[4-(2-hydroxyethyl)piperidin-1-yl]-6,12,15,18-(tetrahydro)ox 
ireno[2', 3':1,9]( $\left.\mathrm{C}_{60}-\mathrm{I}_{\mathrm{h}}\right)[5,6]$ fullerene-incar-dihydrogen $(4 \mathrm{~b})$. A mixture of $\mathrm{H}_{2} @ \mathrm{C}_{60}(1.00$ $\mathrm{mg}, 1.4 \mu \mathrm{mol}$ ) and 4-(hydroxyethyl)piperidine $(1.08 \mathrm{mg}, 8.3 \mu \mathrm{mol})$ in $\mathrm{O}_{2}$-saturated solution of $20 \%$ DMSO in chlorobenzene $(0.1 \mathrm{~mL} / 0.4 \mathrm{~mL})$ was stirred at ambient temperature for $24 \mathrm{~h}$. The yield of the title compound $4 \mathbf{b}$ was estimated to be $78 \%$ by HPLC analysis (ODS column) using 1-acetyl-3-hydroxyindole as an internal standard. The title compound $\mathbf{4 b}$ was isolated and purified by the same procedure reported for $\mathrm{C}_{60}$. The compound has an amphiphilic character and dissolves in various solvents. The ${ }^{1} \mathrm{H}$ NMR spectra of the compound were therefore obtained in various deuterated solvents. ${ }^{1} \mathrm{H}$ NMR $\left(500 \mathrm{MHz}, \mathrm{D}_{2} \mathrm{O} / \mathrm{DMSO}_{6} d_{6} 1 / 9\right) \delta-10.85(\mathrm{~s}, 2 \mathrm{H}$ $(80 \%)$, incar $\left.-\mathrm{H}_{2}\right), 1.11-1.28(\mathrm{~m}, 12 \mathrm{H}), 1.29-1.35(\mathrm{~m}, 2 \mathrm{H}), 1.36-1.51(\mathrm{~m}, 2 \mathrm{H}), 1.52-1.64(\mathrm{~m}$, $2 \mathrm{H}), 1.70-1.82(\mathrm{~m}, 2 \mathrm{H}), 1.97-2.16(\mathrm{~m}, 22 \mathrm{H}), 2.72-2.81(\mathrm{~m}, 2 \mathrm{H}), 3.13-3.22(\mathrm{~m}, 2 \mathrm{H})$, 3.33-3.47 (m, 6H); ${ }^{1} \mathrm{H}$ NMR (500 MHz, DMSO- $\left.d_{6}\right) \delta-10.80\left(\mathrm{~s}, 2 \mathrm{H}(80 \%)\right.$, incar- $\left.\mathrm{H}_{2}\right)$, 1.20-1.31 (br m, 8H), 1.38-1.46 (br m, 12H), 1.74-1.87 (br m, 8H), 2.72-2.79 (br m, 2H), 2.85-3.13 (br m, 6H), 3.43-3.60 (m, 12H), $3.67(\mathrm{~d}, J=12 \mathrm{~Hz}, 2 \mathrm{H}), 3.81(\mathrm{~d}, J=12 \mathrm{~Hz}, 2 \mathrm{H})$, $4.37(\mathrm{t}, J=6 \mathrm{~Hz}, 2 \mathrm{H}), 4.38(\mathrm{t}, J=6 \mathrm{~Hz}, 2 \mathrm{H}) ;{ }^{1} \mathrm{H}$ NMR $\left(400 \mathrm{MHz}\right.$, DMSO- $d_{6} /$ toluene- $d_{8}$ $1 / 1) \delta-10.76\left(\mathrm{~s}, 2 \mathrm{H}(80 \%)\right.$, incar $\left.-\mathrm{H}_{2}\right), 1.38-2.20(\mathrm{br} \mathrm{m}, 28 \mathrm{H}), 2.78-2.90(\mathrm{~m}, 10 \mathrm{H})$, 2.90-3.17 (m, 6H), 3.80-4.14 (m, 8H), 4.69-4.83 (m, 4H); ${ }^{1} \mathrm{H}$ NMR (400 MHz, THF- $\left.d_{8}\right) \delta$ $-10.74\left(\mathrm{~s}, 2 \mathrm{H}(80 \%)\right.$, incar $\left.-\mathrm{H}_{2}\right), 1.47-1.66(\mathrm{~m}, 20 \mathrm{H}), 1.82-1.96(\mathrm{~m}, 8 \mathrm{H}), 2.63-2.72(\mathrm{~m}, 2 \mathrm{H})$, 2.72-2.91 (m, 6H), 3.19-3.30 (m, 4H), 3.30-3.42 (m, 8H), $3.78(\mathrm{~d}, J=13 \mathrm{~Hz}, 2 \mathrm{H}), 3.94(\mathrm{~d}$, $J=13 \mathrm{~Hz}, 2 \mathrm{H}$ ); MS (APCI) calcd for $\left[\mathrm{M}^{+}\right] 1250$, found 1250 . 


\section{X-ray Crystallographic Data for 2 and 3}

Single crystals of 2 and $\mathbf{3}$ suitable for X-ray diffraction studies were grown and subjected to data collection. The data sets were collected on a MacScience DIP2030 Imaging Plate diffractometer using MoK $\alpha$ (graphite monochromated, $\lambda=$ $0.71069 \AA$ A) radiation. Crystal data and data statistics are summarized in Table S1. The structure of 2 and 3 was solved by the direct method (SIR97). ${ }^{1}$ The positional and thermal parameters of non-hydrogen atoms were refined anisotropically on $F^{2}$ by the full-matrix least-squares method, using SHELXL-97. ${ }^{2}$ Encapsulated $\mathrm{H}_{2}$ molecules are placed at differential Fourier peak and refined isotropically. Another hydrogen atoms were placed at calculated positions and refined riding on their corresponding carbon atoms. In the subsequent refinement, the function $\Sigma \omega\left(F_{0}{ }^{2}-F_{c}^{2}\right)^{2}$ was minimized, where $\left|F_{\mathrm{O}}\right|$ and $\left|F_{\mathrm{C}}\right|$ are the observed and calculated structure factor amplitudes, respectively. The agreement indices are defined as $R 1=\Sigma\left(|| F_{0} \mid\right.$ $\left.\left|F_{\mathrm{C}}\right| \mid\right) / \Sigma\left|F_{\mathrm{O}}\right|$ and $\mathrm{w} R 2=\left[\Sigma \omega\left(F_{\mathrm{O}}^{2}-F_{\mathrm{c}}^{2}\right)^{2} / \Sigma\left(\omega F_{\mathrm{O}}^{4}\right)\right]^{1 / 2}$. Figure S1 shows ORTEP diagram of the crystal structure of 3 . Figure S2 shows electron density maps (PLATON contour maps) for 2 and 3. 
Table S1. Crystal Data and Structure Analysis Results for 2 and 3.

\begin{tabular}{|c|c|c|}
\hline & $\mathbf{2} \cdot(\mathrm{THF})_{3}$ & $\mathbf{3} \cdot \mathrm{CS}_{2}$ \\
\hline formula & $\mathrm{C}_{114} \mathrm{H}_{74.6} \mathrm{KO}_{6}$ & $\mathrm{C}_{96} \mathrm{H}_{31.6} \mathrm{FeS}_{2}$ \\
\hline crystal system & monoclinic & orthorhombic \\
\hline space group & $C 2 / c($ No. 15$)$ & $P 2_{1} 2_{1} 2_{1}$ (No. 19) \\
\hline$R, R_{w}(I>2 \sigma(I))$ & $0.1348,0.3420$ & $0.0652,0.1661$ \\
\hline$R 1, w R 2$ (all data) & $0.2623,0.4264$ & $0.0743,0.1765$ \\
\hline GOF on $F^{2}$ & 1.163 & 1.021 \\
\hline$a, \AA$ & $23.698(3)$ & $15.167(1)$ \\
\hline$b, \AA$ & $14.500(2)$ & $17.366(2)$ \\
\hline$c, \AA$ & $43.921(5)$ & $20.553(8)$ \\
\hline$\alpha, \operatorname{deg}$ & 90 & 90 \\
\hline$\beta, \operatorname{deg}$ & $98.740(5)$ & 90 \\
\hline$\gamma, \operatorname{deg}$ & 90 & 90 \\
\hline$V, \AA^{3}$ & $14916.8(9)$ & $5413.5(7)$ \\
\hline$Z$ & 8 & 4 \\
\hline$T, \mathrm{~K}$ & $153(2)$ & $153(2)$ \\
\hline crystal size, mm & $0.80,0.50,0.12$ & $0.40,0.15,0.10$ \\
\hline$D_{\text {calcd }}, \mathrm{g} / \mathrm{cm}^{3}$ & 1.407 & 1.601 \\
\hline $2 \theta_{\min }, 2 \theta_{\max }, \mathrm{deg}$ & $4.12,51.38$ & $4.60,51.44$ \\
\hline no. refl. measured (unique) & 57742 & 37937 \\
\hline no. refl. measured $(I>2 \sigma(I))$ & 13738 & 5162 \\
\hline no. parameters & 992 & 901 \\
\hline
\end{tabular}

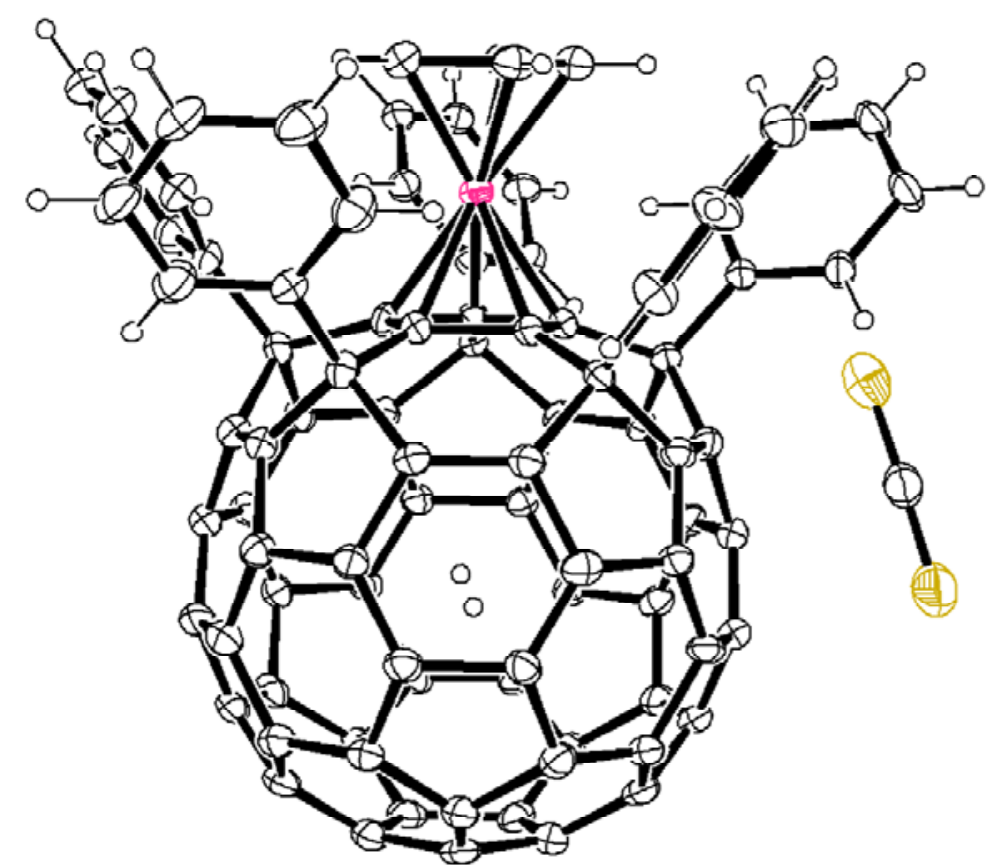

Figure S1. ORTEP drawing of the crystal structure of 3 .

Thermal ellipsoids are drawn in 30\% probability level. 
(a)

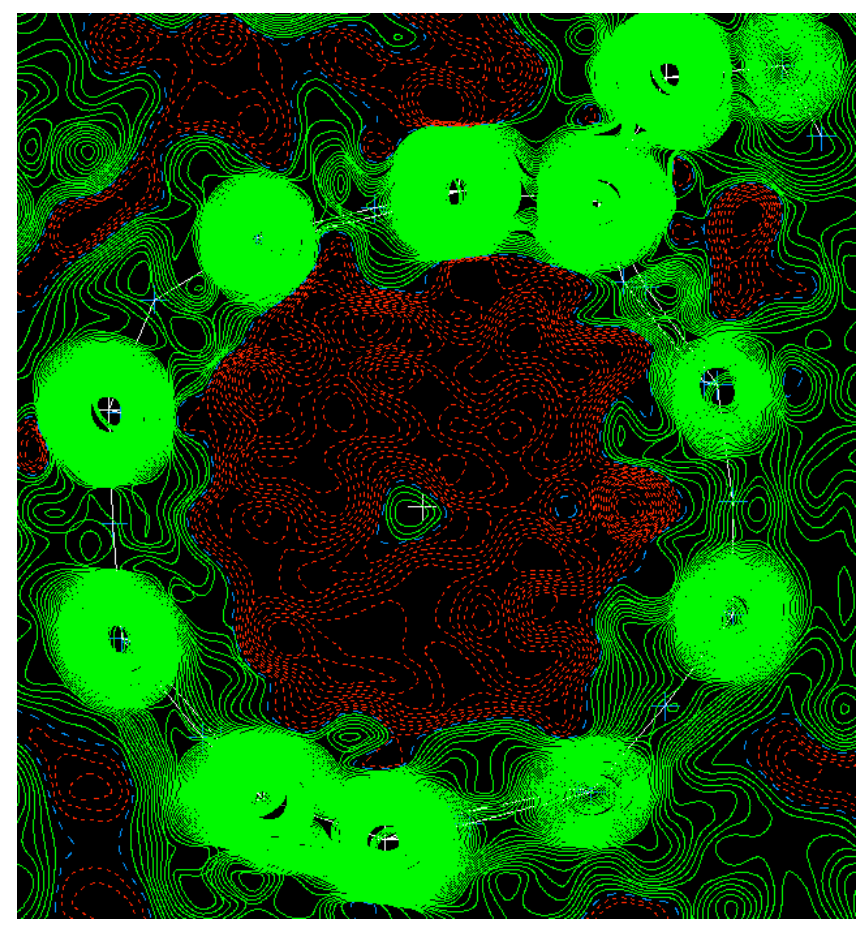

\section{(b)}

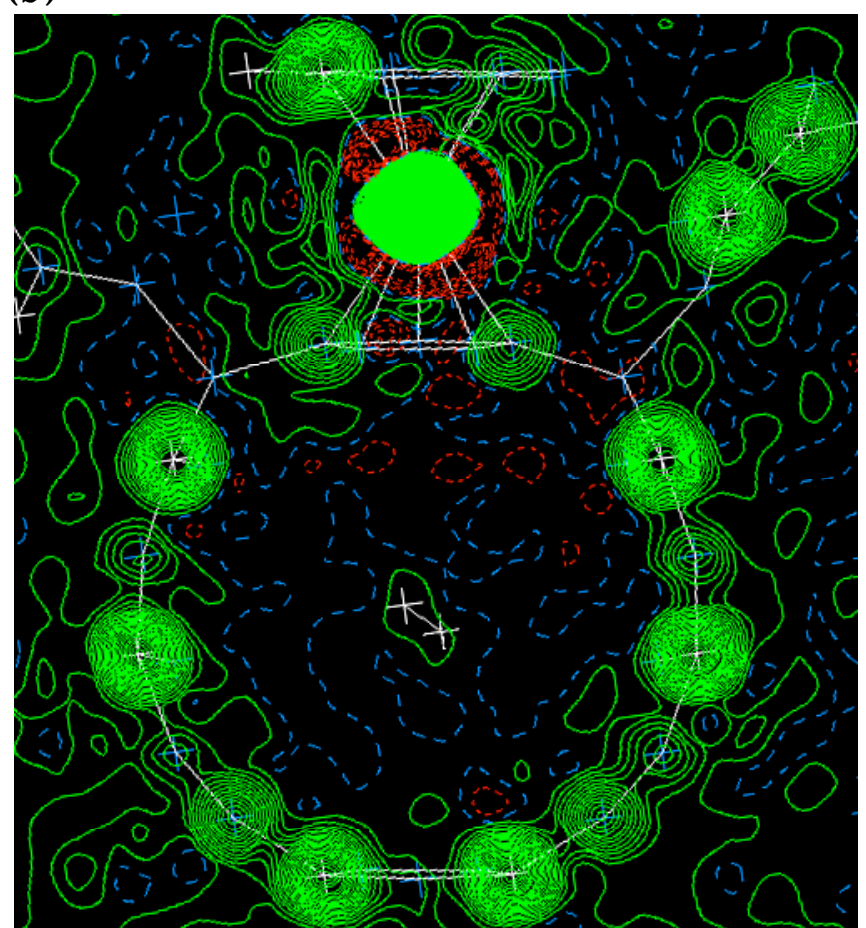

Figure S2. Electron density maps (PLATON contour maps) for 2 and 3. (a) The map for 2. (b) The map for 3. The figures show the cross section around the center area of $\mathrm{C}_{60}$ cages. Green full lines indicate positive electron density. Red dashed lines indicate negative electron density. 


\section{Theoretical Calculation of $\mathrm{C}_{60} \mathrm{H}_{5}$ Anion}

In order to obtain insight about relation between ${ }^{1} \mathrm{H}$ NMR chemical shift and location of $\mathrm{H}_{2}$, we performed theoretical investigation of magnetic anisotropic effect in the fullerene cage. With structural information of X-ray data for 2, geometry optimization calculation of model compound, $\mathrm{C}_{60} \mathrm{H}_{5}$ anion was carried out by the use of hybrid density functional method (B3LYP/6-31G*). Then we estimated nucleus independent chemical shift $(\mathrm{NICS})^{3}$ values by means of gauge-invariant atomic orbital $(\mathrm{GIAO})^{4}$ calculation with Hartree-Fock method $\left(\mathrm{HF} / 6-31 \mathrm{G}^{*}\right)$. The NICS values at the position along molecular $C_{5 v}$ axis is shown in Figure S3. Data showed that the centroid $\mathrm{C}_{60}$ is strongly shielded (NICS $=-6.76$ ) and the shielding effect increase with lower (bottom) part of the cage. This result give us a valuable information to understand deshielding NMR shift of the encapsulated molecular hydrogen in 2. Comparing $\mathrm{H}_{2}$-position determined by X-ray analysis of 2 and $3, \mathrm{H}_{2}$ of $\mathbf{2}$ is located more upper ward than that of $\mathbf{3}$. In other word, molecular hydrogen of $\mathbf{2}$ is in more deshielding region than that of $\mathbf{3}$, and this is consistent with NMR data.

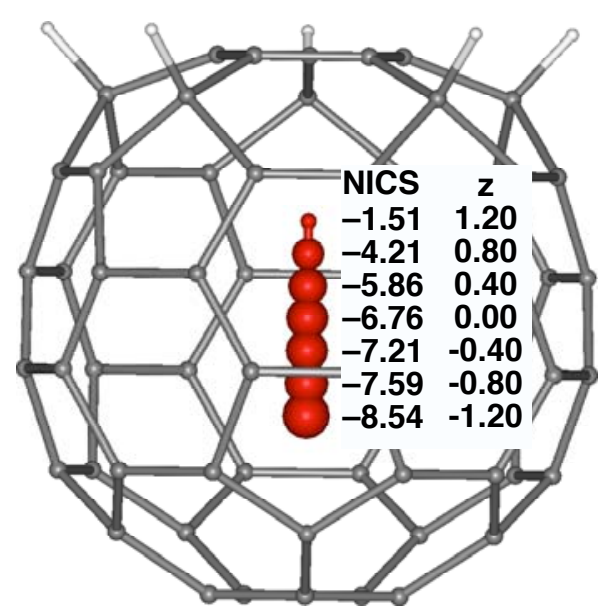

Figure S3. NICS values of inside of the cage. Observation points (red balls) aligned along molecular $C_{5 v}$ axis at interval of $0.40 \AA$. Size of red balls represent magnitude of NICS values. 


\section{NMR and MS Spectra of 1-4}

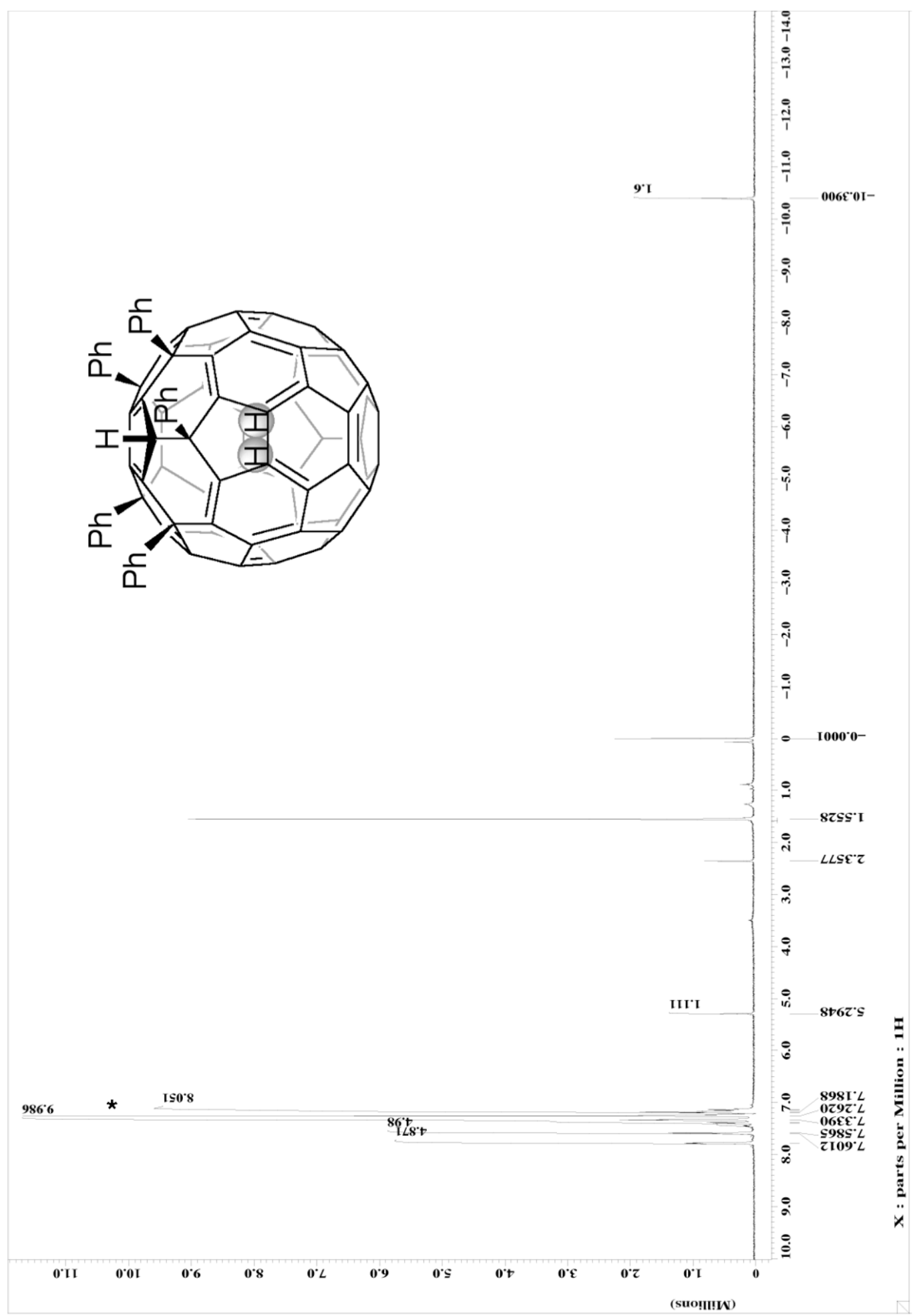

Figure

S4.

${ }^{1} \mathrm{H}$

NMR

spectrum

of

6,9,12,15,18-Pentaphenyl-1,6,9,12,15,18-hexahydro $\left(\mathrm{C}_{60}-I_{\mathrm{h}}\right)[5,6]$ fullerene-incar-dihydro gen in $1: 1 \mathrm{CDCl}_{3} / \mathrm{CS}_{2}$. Asterisk indicate the solvent signal. 


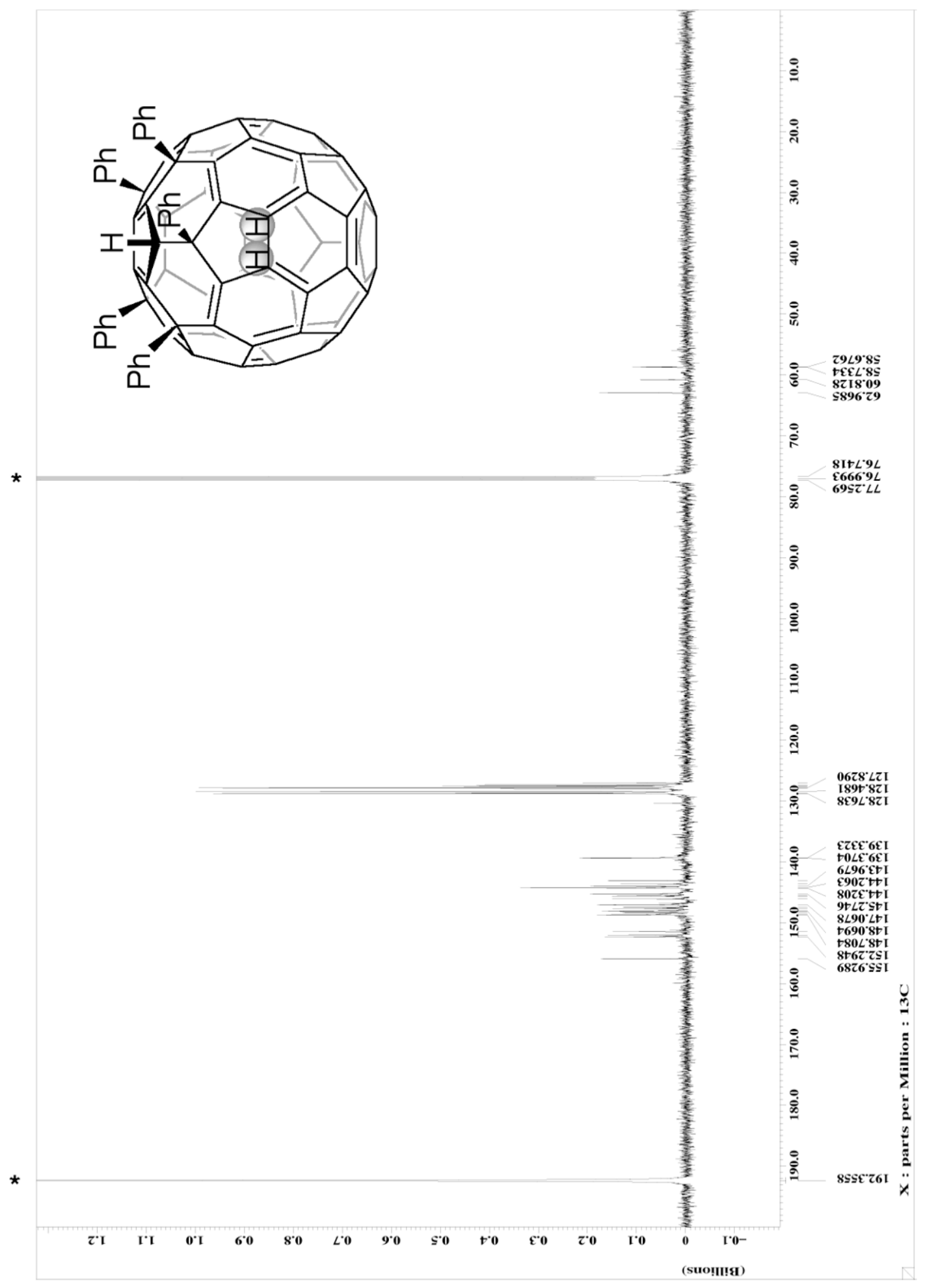

$\begin{array}{lllll}\text { Figure } & \text { S5. } & { }^{13} \mathrm{C} & \mathrm{NMR} & \text { spectrum }\end{array}$ 6,9,12,15,18-Pentaphenyl-1,6,9,12,15,18-hexahydro $\left(C_{60}-I_{h}\right)[5,6]$ fullerene-incar-dihydro gen in $1: 1 \mathrm{CDCl}_{3} / \mathrm{CS}_{2}$. Asterisk indicate the solvent signal. 


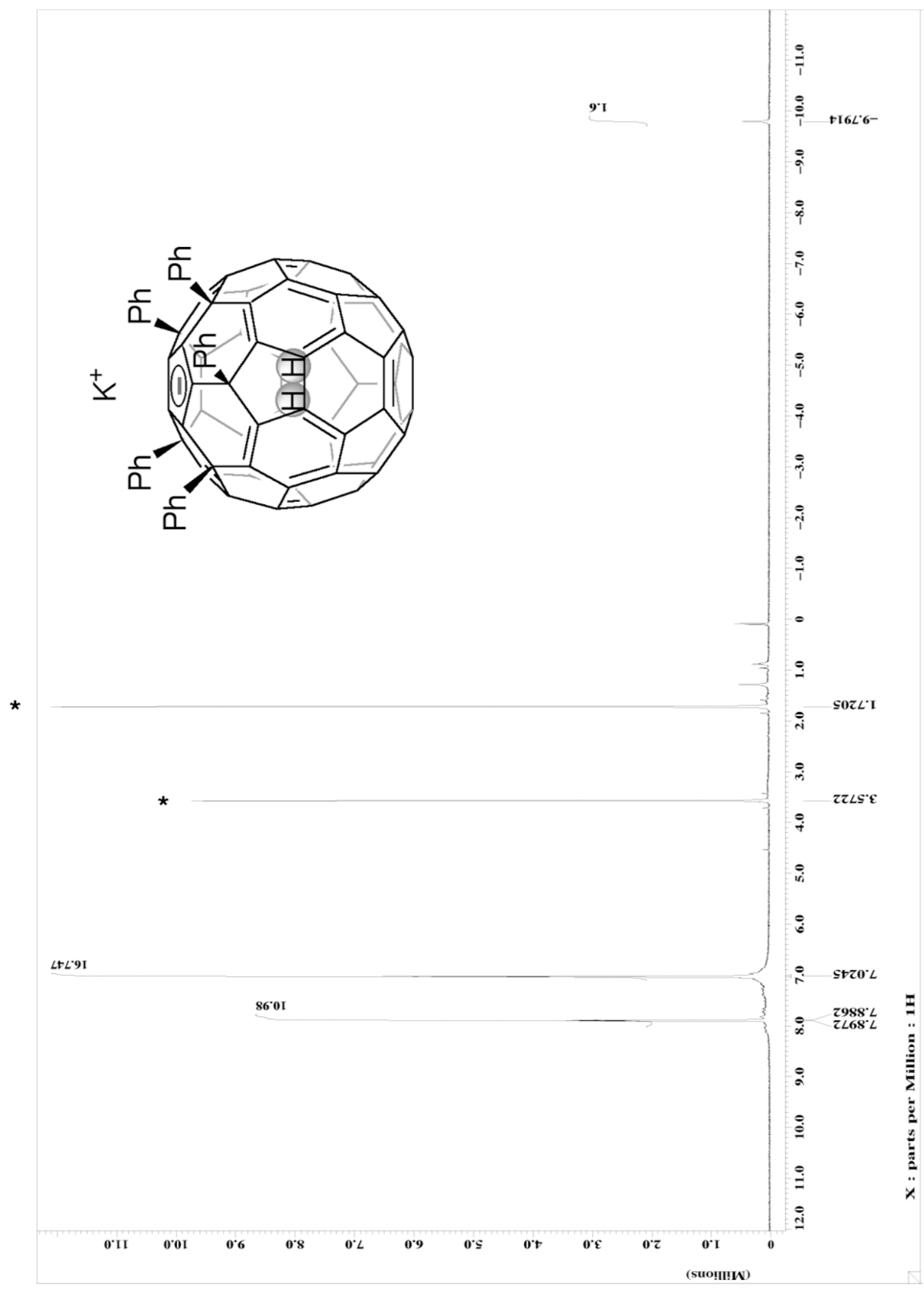

$\begin{array}{lllll}\text { Figure } & \text { S6. } & { }^{1} \mathrm{H} & \text { NMR } & \text { spectrum }\end{array}$ $\left[6,9,12,15,18\right.$-Pentaphenyl-1,6,9,12,15,18-hexahydro $\left(\mathrm{C}_{60}-I_{\mathrm{h}}\right)[5,6]$ fullerene-incar-dihydro gen-1(6H)-yl]potassium in THF- $d_{8}$. Asterisk indicate the solvent signal. 


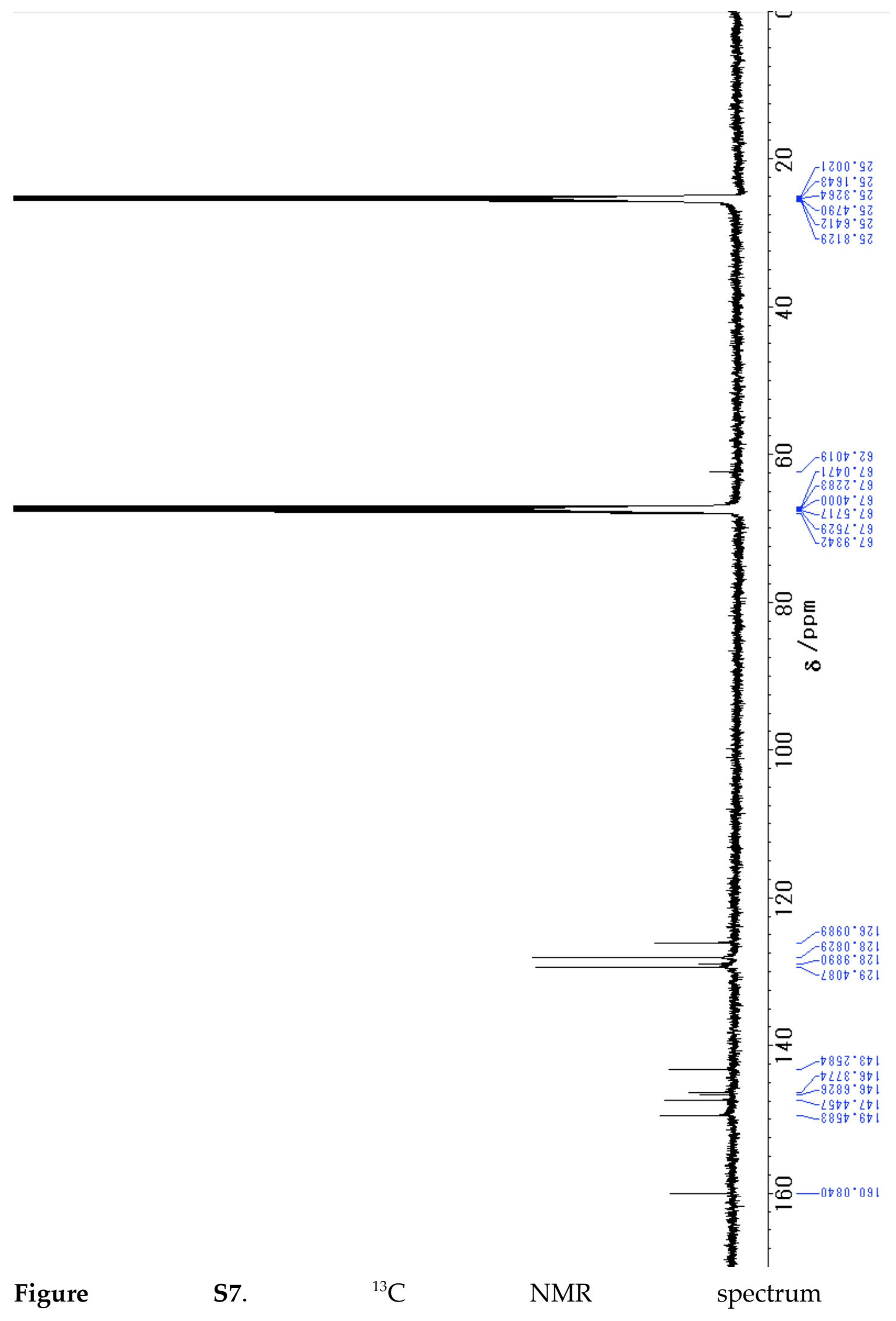

of

$\left[6,9,12,15,18\right.$-Pentaphenyl-1,6,9,12,15,18-hexahydro $\left(\mathrm{C}_{60}-I_{\mathrm{h}}\right)[5,6]$ fullerene-incar-dihydro gen-1(6H)-yl]potassium in THF- $d_{8}$. 


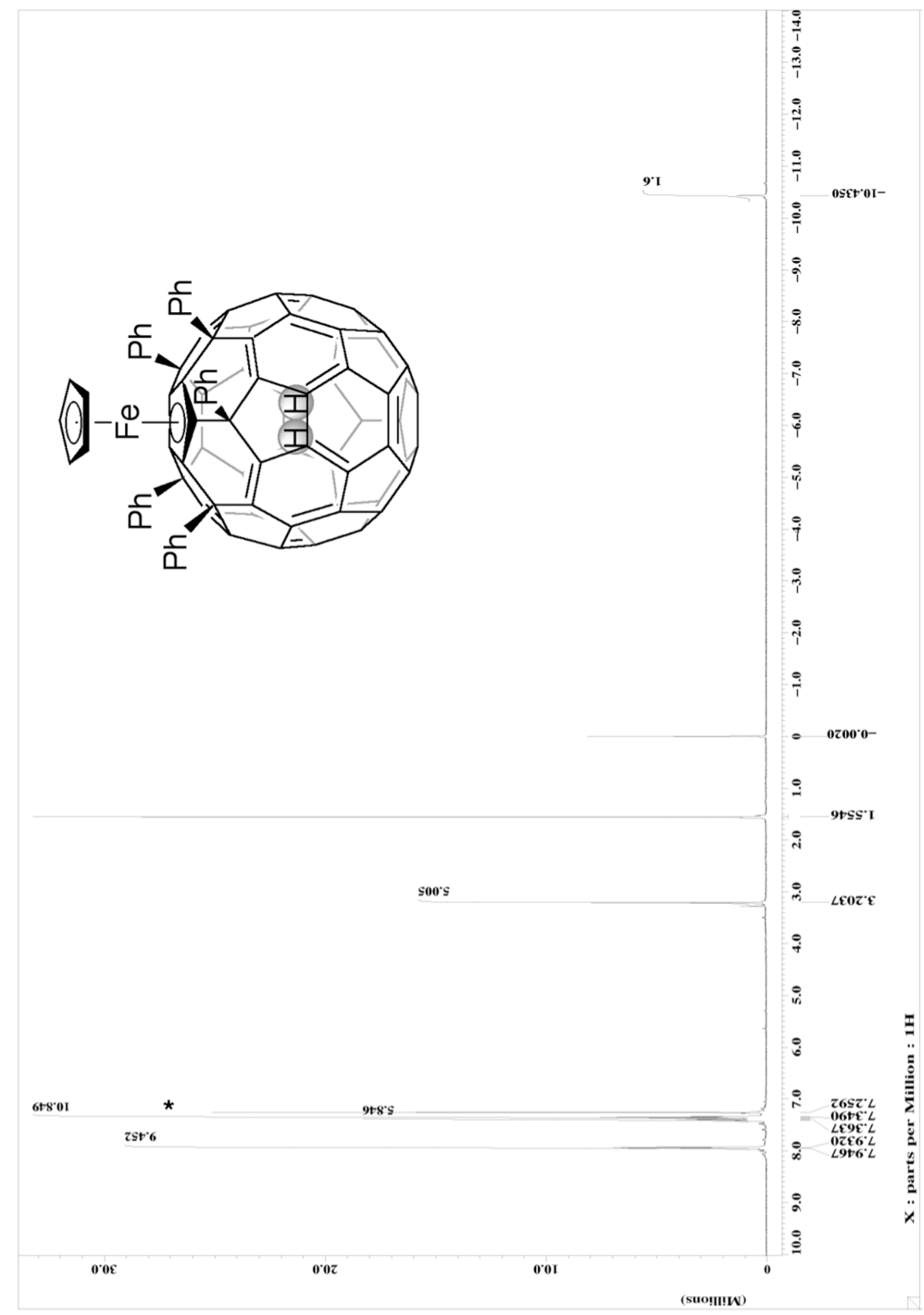

$\begin{array}{lllll}\text { Figure } & \text { S8. } & { }^{1} \mathrm{H} & \mathrm{NMR} & \text { spectrum }\end{array}$ ( $\eta^{5}$-cyclopentadienyl) $\left[6,9,12,15,18\right.$-Pentaphenyl-1,6,9,12,15,18-hexahydro $\left(\mathrm{C}_{60}-I_{\mathrm{h}}\right)[5,6] \mathrm{f}$ ullerene-incar-dihydrogen-1(6H)-yl]iron(II) in $1: 1 \mathrm{CDCl}_{3} / \mathrm{CS}_{2}$. Asterisk indicate the solvent signal. 


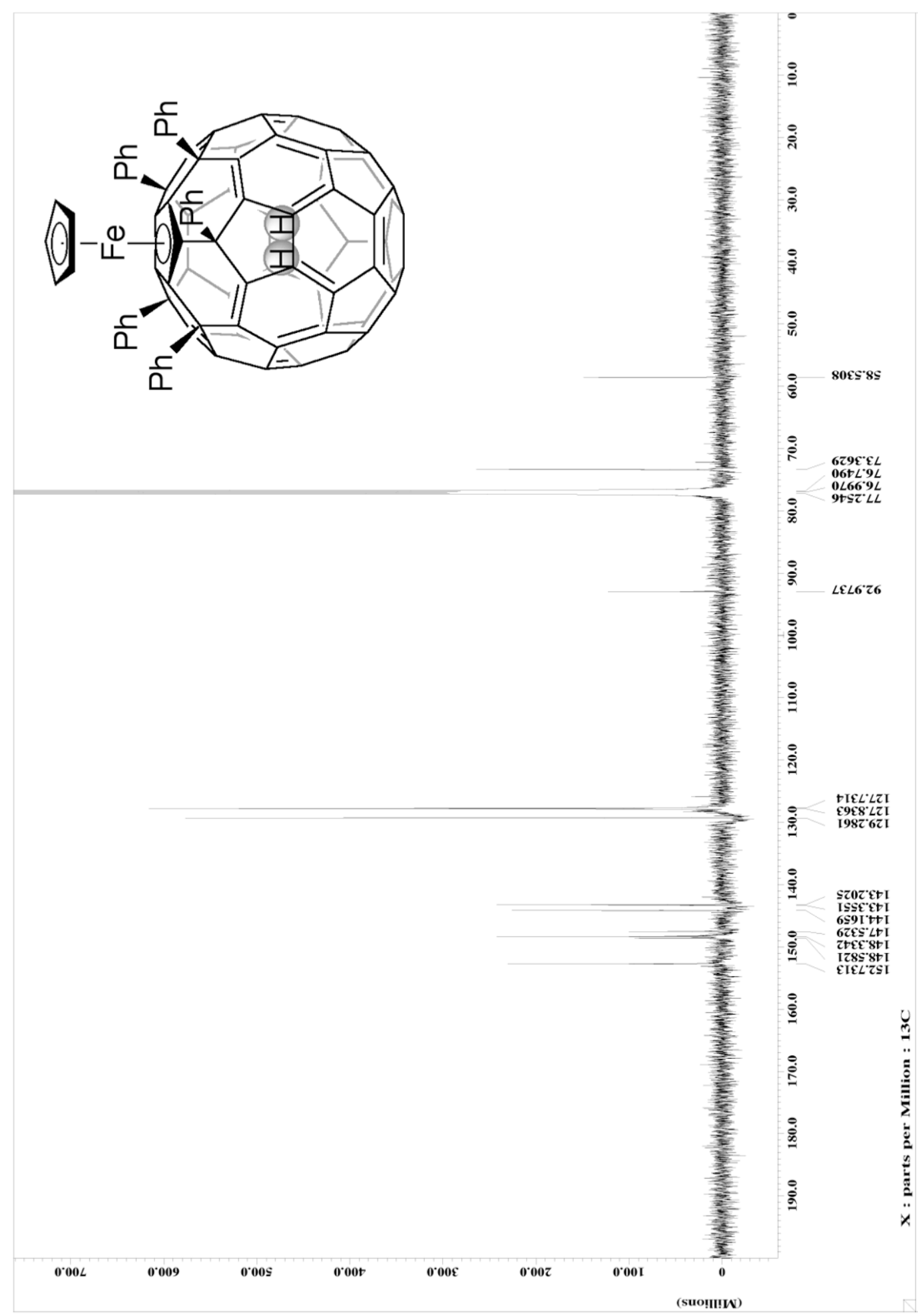

$\begin{array}{lllll}\text { Figure } & \text { S9. } & { }^{13} \mathrm{C} & \mathrm{NMR} & \text { spectrum }\end{array}$ $\left(\eta^{5}\right.$-cyclopentadienyl)[6,9,12,15,18-Pentaphenyl-1,6,9,12,15,18-hexahydro $\left(\mathrm{C}_{60}-I_{\mathrm{h}}\right)[5,6] \mathrm{f}$ ullerene-incar-dihydrogen-1(6H)-yl]iron(II) in $1: 1 \mathrm{CDCl}_{3} / \mathrm{CS}_{2}$. Asterisk indicate the solvent signal. 


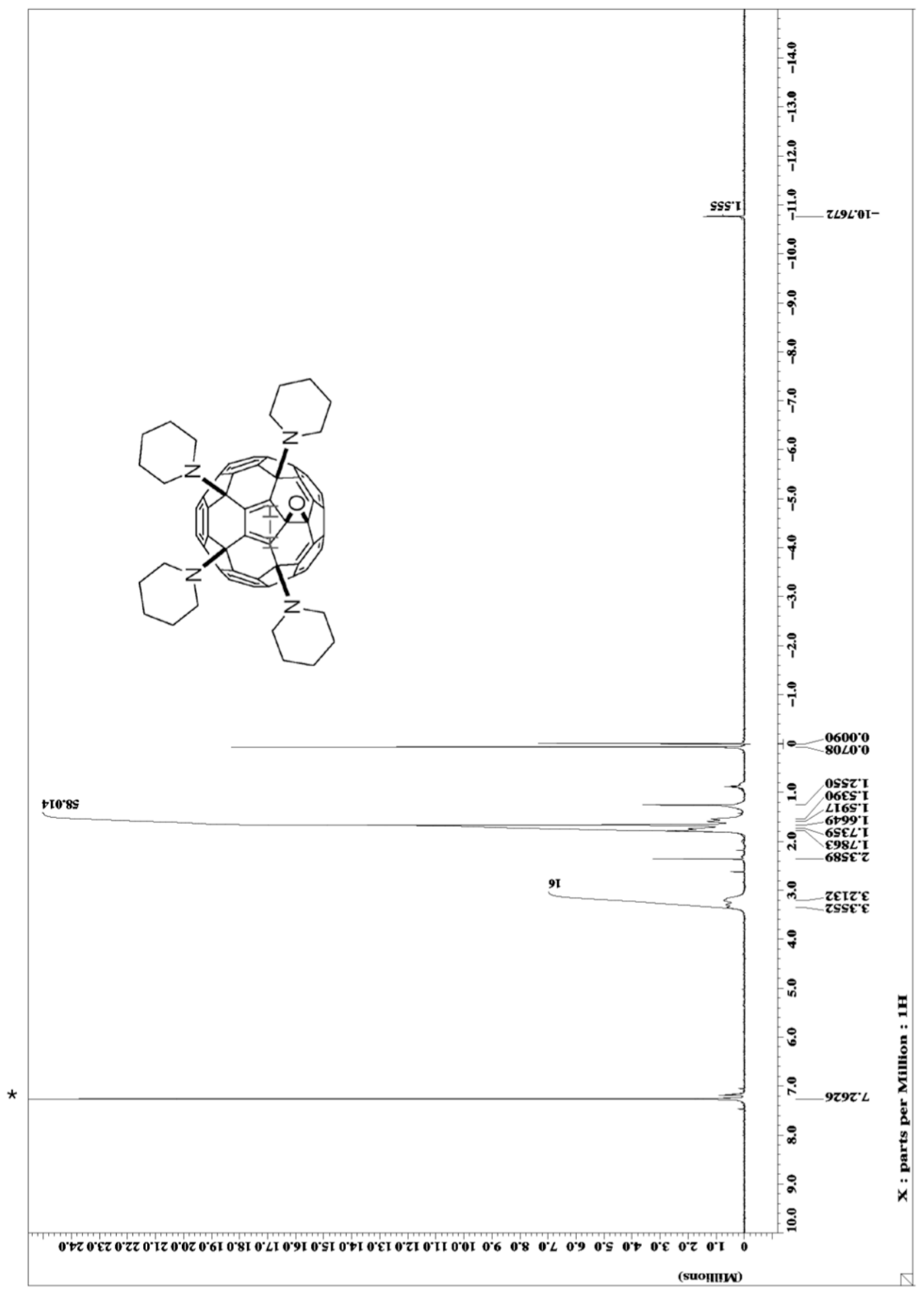

$\begin{array}{lllll}\text { Figure } & \text { S10. } & { }^{1} \mathrm{H} & \text { NMR } & \text { spectrum }\end{array}$ 6,12,15,18-Tetra(piperidin-1-yl)-6,12,15,18-(tetrahydro)oxireno[2',3':1,9](C60-I $\left.I_{h}\right)[5,6]$ full erene-incar-hydrogen in $\mathrm{CDCl}_{3}$. Asterisk indicate the solvent signal. 

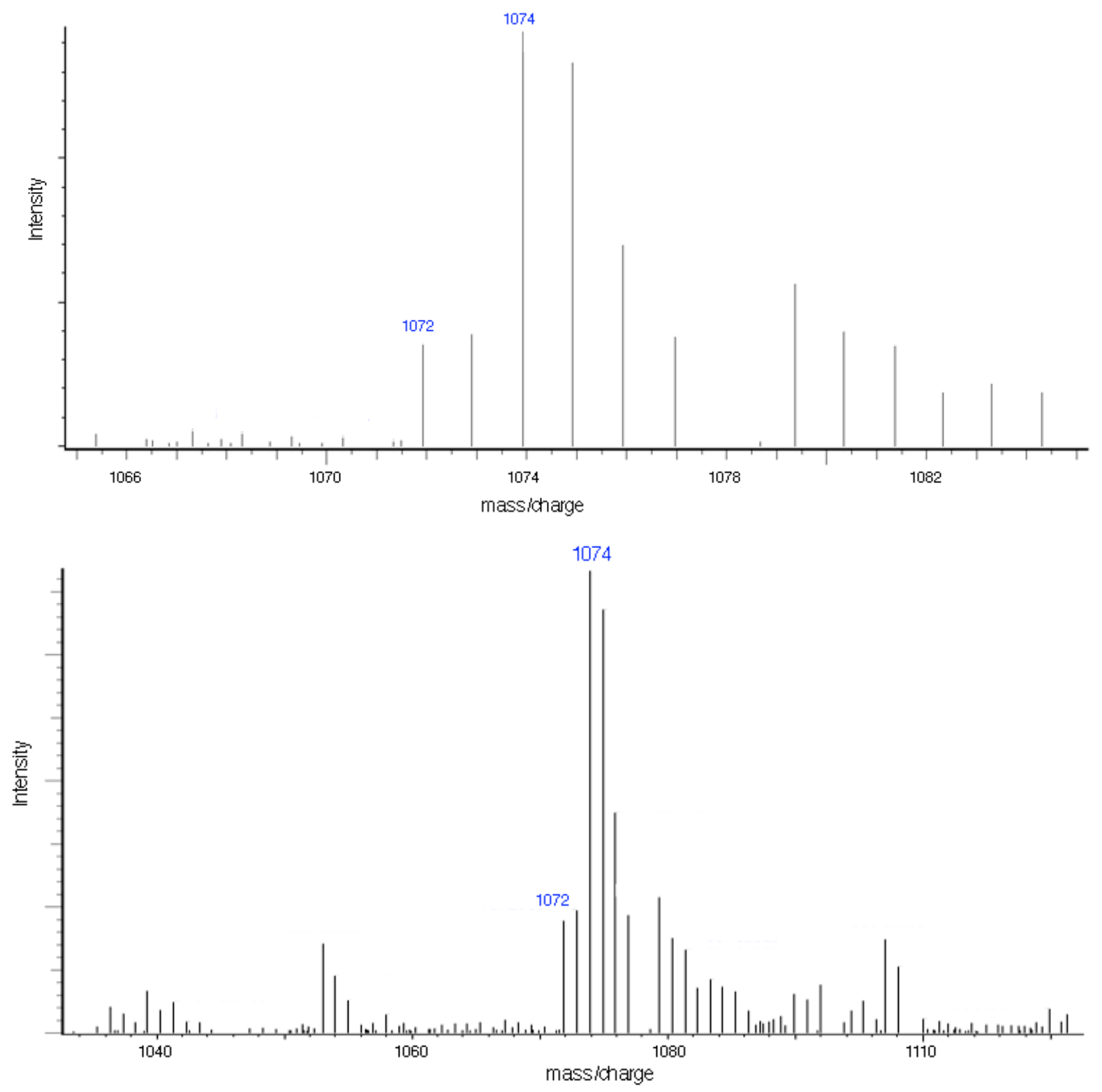

Figure

S11.

MS

spectrum

of

6,12,15,18-Tetra(piperidin-1-yl)-6,12,15,18-(tetrahydro)oxireno[2',3':1,9](C60- $\left.I_{\mathrm{h}}\right)[5,6]$ full erene-incar-hydrogen. 


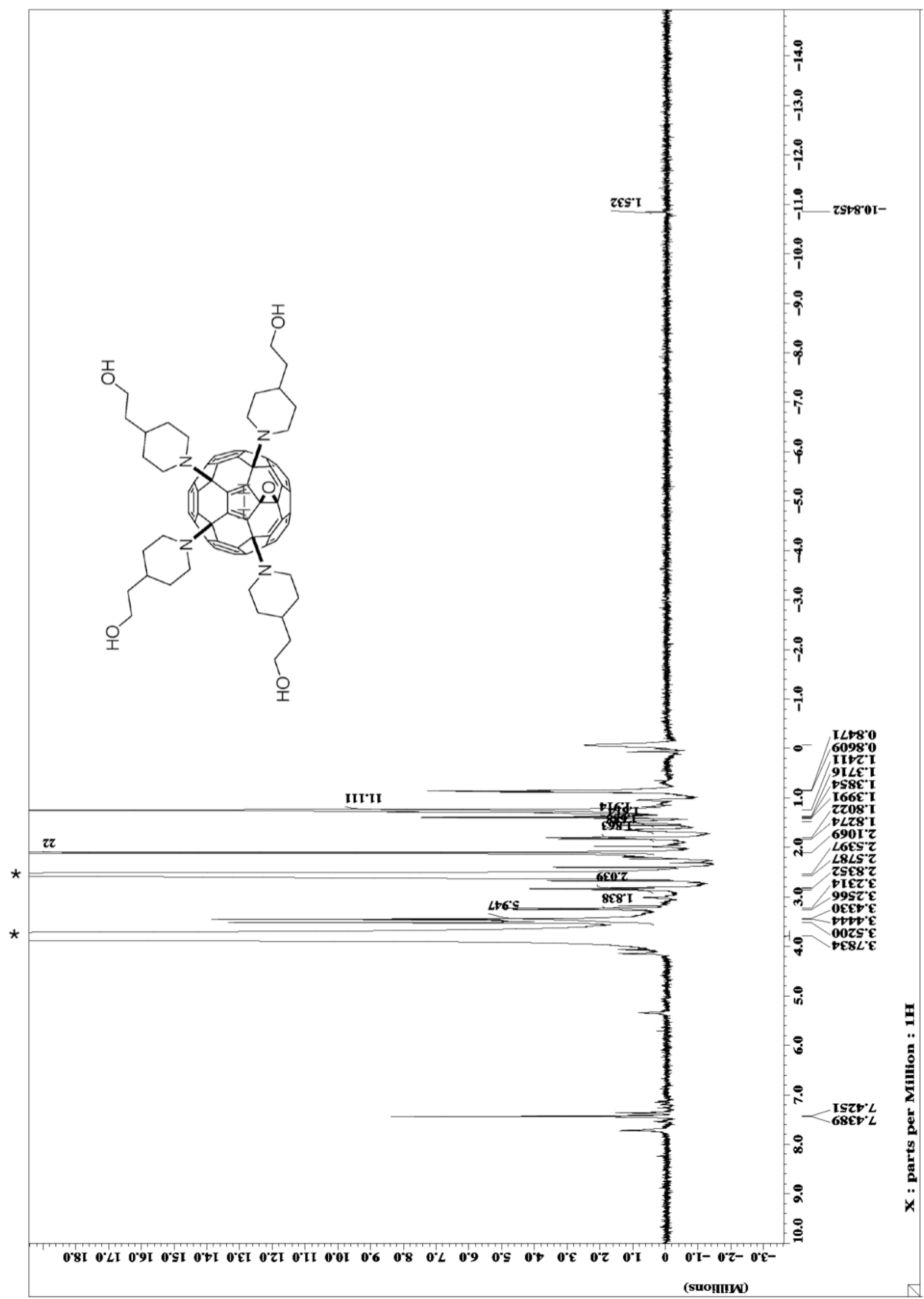

$\begin{array}{lllll}\text { Figure } & \text { S12. } & { }^{1} \mathrm{H} & \text { NMR } & \text { spectrum }\end{array}$ 6,12,15,18-Tetra[4-(2-hydroxyethyl)piperidin-1-yl]-6,12,15,18-(tetrahydro)oxireno[2',3 ':1,9] $\left(\mathrm{C}_{60}-\mathrm{I}_{\mathrm{h}}\right)[5,6]$ fullerene-incar-hydrogen in 1:9 $\mathrm{D}_{2} \mathrm{O} / \mathrm{DMSO}-\mathrm{d}_{8}$. Asterisks indicate the solvent signals. 


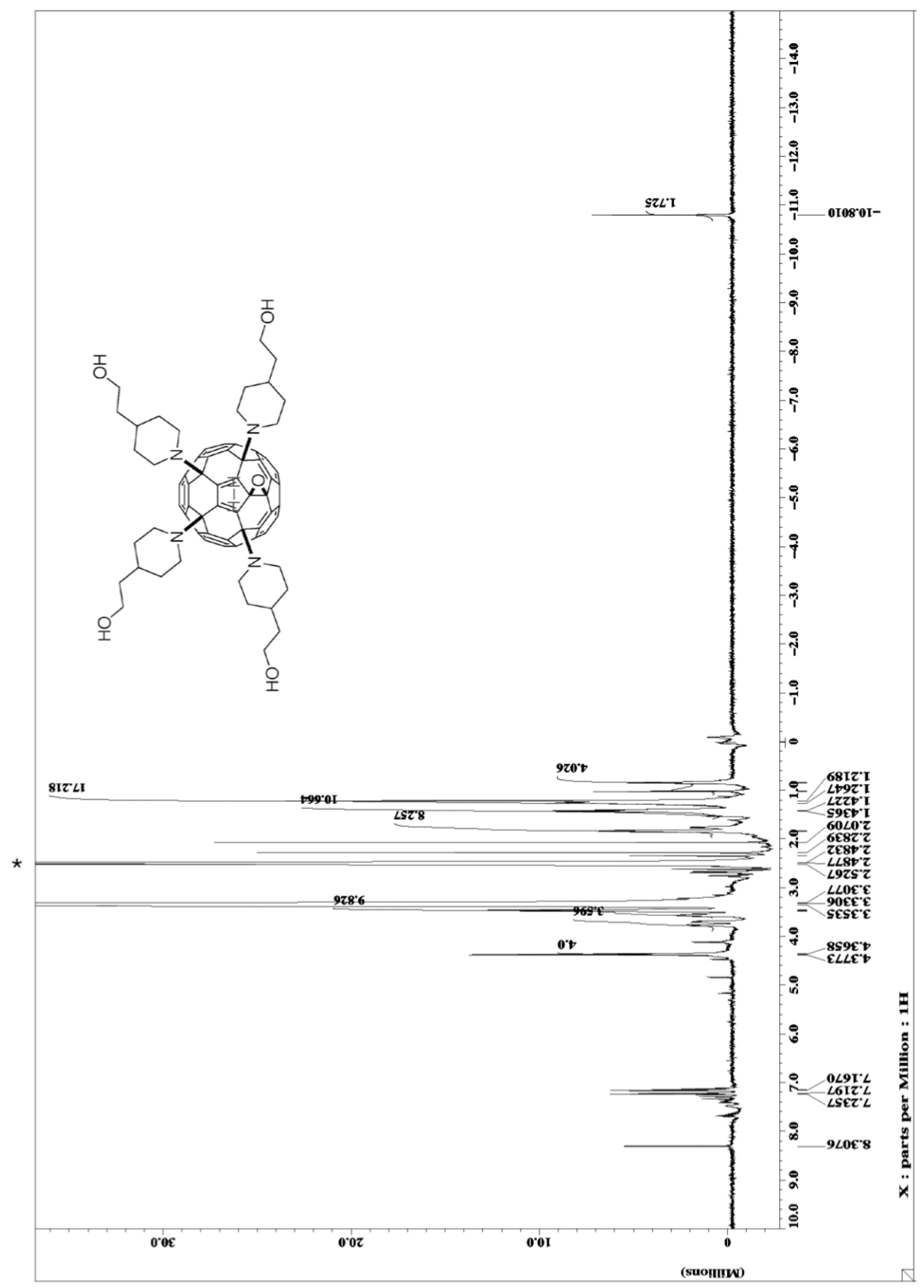

$\begin{array}{lllll}\text { Figure } & \text { S13. } & { }^{1} \mathrm{H} & \text { NMR } & \text { spectrum }\end{array}$ 6,12,15,18-Tetra[4-(2-hydroxyethyl)piperidin-1-yl]-6,12,15,18-(tetrahydro)oxireno[2',3 $': 1,9]\left(\mathrm{C}_{60}-\mathrm{Ih}_{\mathrm{h}}\right)[5,6]$ fullerene-incar-hydrogen in DMSO- $\mathrm{d}_{6}$. Asterisk indicate the solvent signal. 


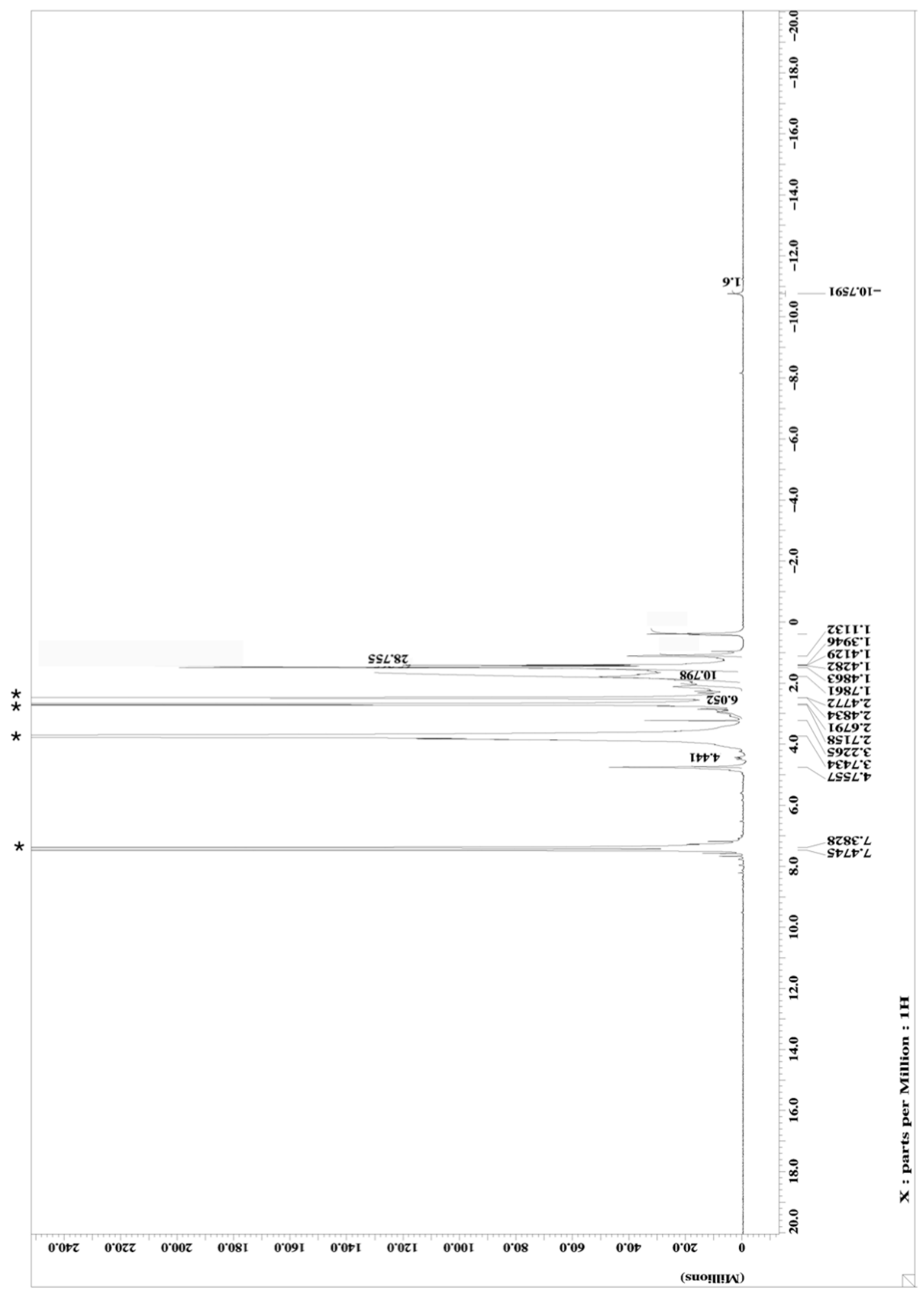

$\begin{array}{lllll}\text { Figure } & \text { S14. } & { }^{1} \mathrm{H} & \text { NMR } & \text { spectrum }\end{array}$

6,12,15,18-Tetra[4-(2-hydroxyethyl)piperidin-1-yl]-6,12,15,18-(tetrahydro)oxireno[2',3 ':1,9] $\left(\mathrm{C}_{60}-\mathrm{I}_{\mathrm{h}}\right)[5,6]$ fullerene-incar-hydrogen in $1: 1$ DMSO- $\mathrm{d}_{6} /$ toluene- $\mathrm{d}_{8}$. Asterisks indicate the solvent signals. 


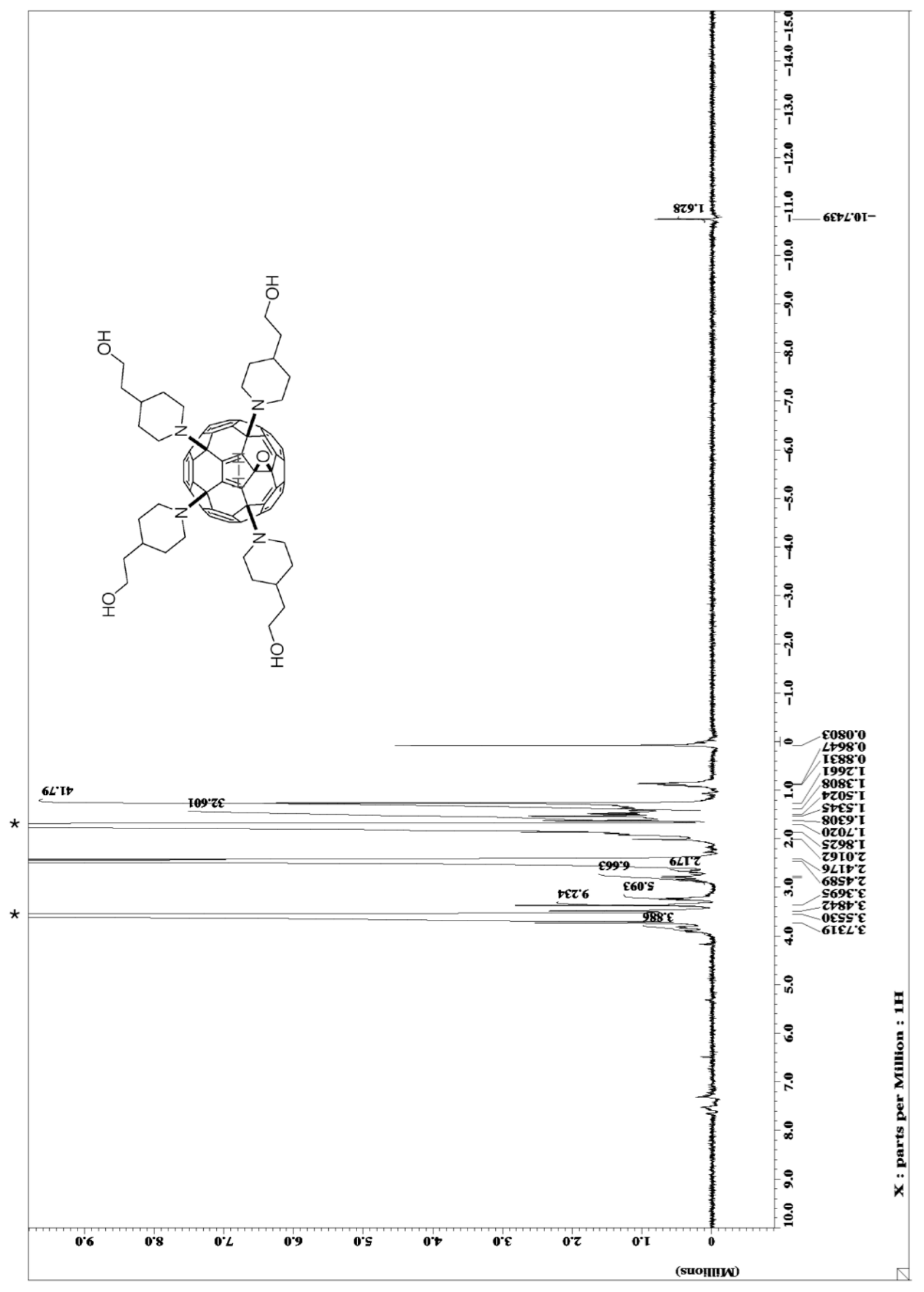

$\begin{array}{lllll}\text { Figure } & \text { S15. } & { }^{1} \mathrm{H} & \text { NMR } & \text { spectrum }\end{array}$

6,12,15,18-Tetra[4-(2-hydroxyethyl)piperidin-1-yl]-6,12,15,18-(tetrahydro)oxireno[2',3 ':1,9] $\left(\mathrm{C}_{60}-\mathrm{I}_{\mathrm{h}}\right)[5,6]$ fullerene-incar-hydrogen in $\mathrm{THF}_{8} \mathrm{~d}_{8}$. Asterisks indicate the solvent signals. 

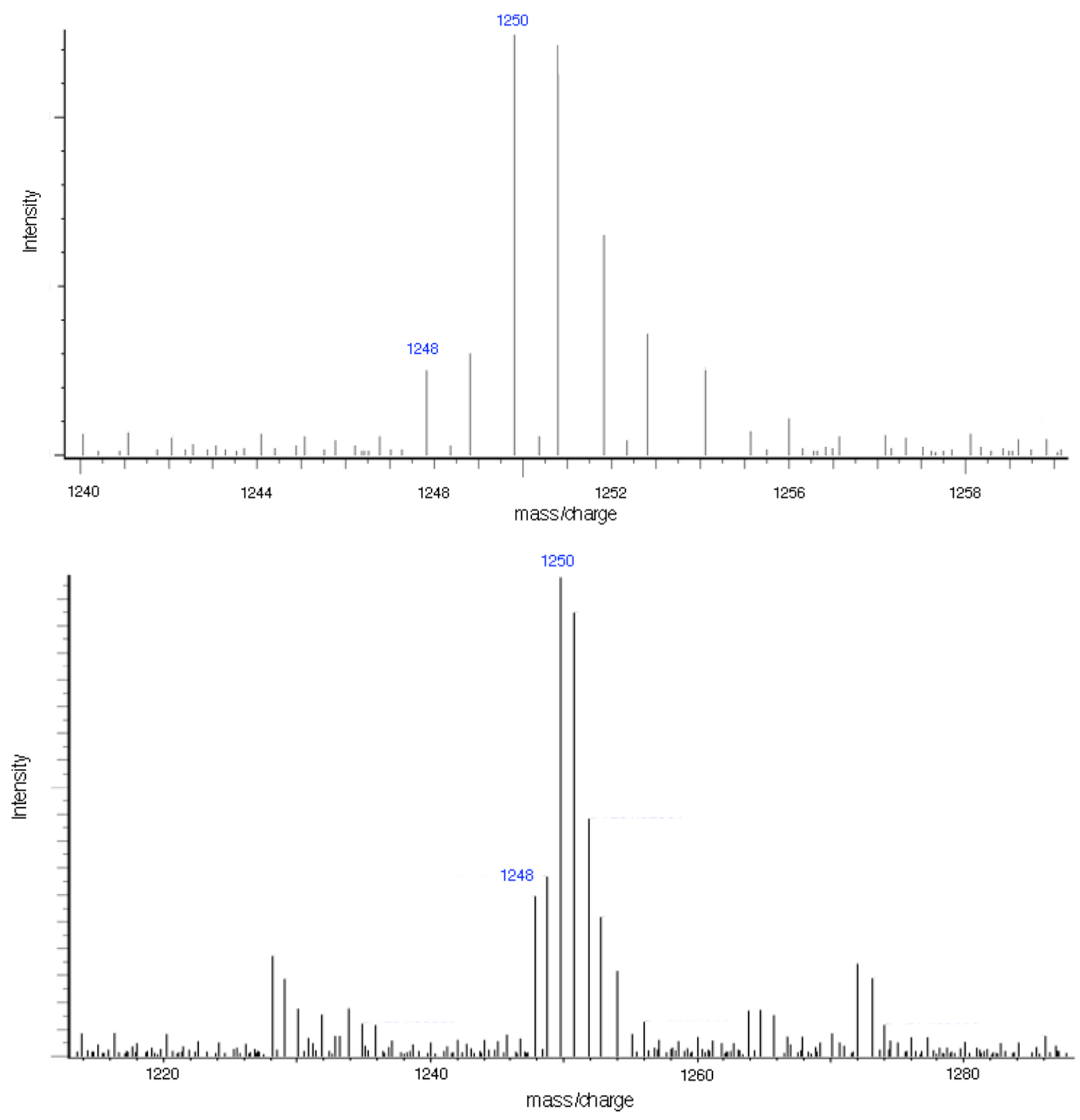

$\begin{array}{llll}\text { Figure } & \text { S16. } & \text { MS } & \text { of }\end{array}$

6,12,15,18-Tetra[4-(2-hydroxyethyl)piperidin-1-yl]-6,12,15,18-(tetrahydro)oxireno[2',3 $': 1,9]\left(\mathrm{C}_{60}-\mathrm{Ih}_{\mathrm{h}}\right)[5,6]$ fullerene-incar-hydrogen. 


\section{References}

S1. Altomare, A.; Burla, M. C.; Camalli, M; Cascarano, G. L.; Giacovazzo, C.; Guagliardi, A.; Moliterni, A. G. G.; Polidori, G.; Spagna, R. J. Appl. Cryst. 1999, $32,115-119$.

S2. Programs for Crystal Structure Analysis (Release 97-2). Sheldrick, G. M.; Institut für Anorganische Chemie der Universität, Tammanstrasse 4, D-3400 Götingen, Germany, 1998.

S3. (a) Schleyer, P. v. R.; Maerker, C.; Dransfeld, A.; Jiao, H.; Hommes, N. J. R. van E. J. Am. Chem. Soc. 1996, 118, 6317. (b) Bühl, M.; Hirsch, A. Chem. Rev. 2001, 101, 1153.

S4. Helgaker, T.; Jaszunski, M.; Ruud, K. Chem. Rev. 1999, 99, 293-352. 